\title{
In silico Nigellidine (N. sativa) bind to viral spike/active-sites of ACE1/2, AT1/2 to prevent COVID-19 induced vaso-tumult/vascular-damage/comorbidity
}

\author{
Smarajit Maiti ${ }^{1}$, Amrita Banerjee ${ }^{1}$, and Mehak Kanwar ${ }^{1}$ \\ ${ }^{1}$ Affiliation not available
}

July 8, 2020

\begin{abstract}
COVID-19 is the global-pandemic targets human-lung-ACE2 that converts Angiotensin-II to (1-7) peptide causing vasodilatation. Vasoconstriction caused by Angiotensin-II is produced from Angiotensin-I by ACE1. The vaso-status maintains bloodpressure/vascular-health of the individuals which is demolished in Covid-19 infection manifesting aldosterone/salt-deregulations/inflammations/ende dysfunctions/hyper-hypo- tension, sepsis/hypovolemic-shock and vessel-thrombosis/coagulations. These cause comorbidity patients. Here, nigellidine, an indazole-alkaloid was analyzed by molecular-docking for binding to different Angiotensin-bindingproteins (enzymes, ACE1(6en5)/ACE2(4aph)/receptors, AT1(6os1)/AT2(5xjm)) and COVID-19 spike-glycoprotein(6vsb). Data suggest that nigellidine strongly binds to the spike-protein at the hinge-region/active-site-opening which may hamper properbinding of nCoV2-ACE2 surface. Nigellidine strongly (-7.54 kcal/mol, -211.76, Atomic-Contact-Energy; ACE-value) binds (>known-binderEGCG; -4.53 and Theaflavin-di-gallate; -2.85$)$ in the Angiotensin-II binding-site/entry-pocket at ACE2 with Ki 8.68 and $8.3 \mu \mathrm{mol}$. Further, Nigellidine showed strong-binding (best Ki, 50.93umol/binding-energy $-5.48 \mathrm{kcal} / \mathrm{mol}$ ) to both mono- and multi-meric ACE1-forms. Moreover, this compound binds Angiotensin-receptors, AT1/AT2 (Ki, $42.79 / 14.22$ $\mu \mathrm{mol}$, binding-energy, $-5.96 /-6.61 \mathrm{kcal} / \mathrm{mol}$ ) at active-sites, respectively. Here, we first-time report that nigellidine can block all angiotensin-binding proteins where, the Angiotensin-bonded amino acids were more or less similar/analogous and effectively blocked by nigellidine. The ACEs-blocking could restore Angiotensin-level and restrict vaso-turbulence in Covid-infected patients and receptor-blocking might stop inflammatory/vascular impairment. Further, nigellidine may slowdown the vasofluctuations due to Angiotensin deregulations in Covid-infected patients. Angiotensin II-ACE2 binding (ACE-value -294.81) is more favorable than nigellidine-ACE2. Contrarily, nigellidine-ACE1 binding-energy/Ki are lower than nigellidine-ACE2 values indicating a balanced-state between constriction-dilatation. It is also noticed that nigellidine binds to the viral-spike, closer proximity to its ACE2 binding-domain. Taken together, Covid-infected-patients/elderly-patients/comorbid-patients (with hypertensive/diabetic/cardiac/renal impairment, counting $>90 \%$ of non-survivors) could be greatly benefited.
\end{abstract}

\section{Hosted file}

nigellidine and COVID.docx available at https://authorea.com/users/341011/articles/467994in-silico-nigellidine-n-sativa-bind-to-viral-spike-active-sites-of-ace1-2-at1-2-to-

prevent-covid-19-induced-vaso-tumult-vascular-damage-comorbidity 